\title{
Childhood body mass index at 5.5 years mediates the effect of prenatal maternal stress on daughters' age at menarche: Project Ice Storm - ERRATUM
}

\author{
A. Duchesne, A. Liu, S. L. Jones, D. P. Laplante and S. King
}

First published online 6 February 2017

doi: 10.1017/S2040174416000726. Published by Cambridge University Press, 28 December 2016.

In the abstract section of the above article, the sentence:

A total of 31 girls, whose mothers were exposed to the Quebec's January 1998 ice storm during pregnancy were followed from 6 months to $51 / 2$ to 5.5 years of age.

Should have read:

A total of 31 girls, whose mothers were exposed to the Quebec's January 1998 ice storm during pregnancy were followed from 6 months to 15.5 years of age.

\section{Reference}

1. Duchesne A, Liu A, Jones SL, Laplante DP, King S. Childhood body mass index at 5.5 years mediates the effect of prenatal maternal stress on daughters' age at menarche: Project Ice Storm. Journal of Developmental Origins of Health and Disease. Published online by Cambridge University Press 28 December 2016, https://doi.org/10.1017/S2040174416000726. 